\title{
COMO HABERMAS SE SITUA NO CENÁRIO DO PENSAMENTO CONTEMPORÂNEO
}

\author{
Manfredo Araújo de Oliveira ${ }^{1}$
}

\section{Resumo}

Habermas levanta a pretensão de repensar a filosofia transcendental a partir da reviravolta linguística e articular a filosofia como um "pragmatismo kantiano", pondo no centro a primazia da dimensão pragmática. No lugar da subjetividade transcendental da consciência se põe a "intersubjetividade destranscendentalizada" do mundo da vida. Isto revela uma tarefa fundamental da filosofia hoje: desempenhar o papel de "intérprete" entre as culturas especializadas, ciência, tecnologia, direito e moralidade, e as práticas comunicativas da vida cotidiana. Ele tem consciência de que a reinterpretação da esfera transcendental como nossas práticas intersubjetivas quotidianas trouxe de volta justamente os problemas que Kant pretendeu superar com a filosofia transcendental: o relativismo e o ceticismo. Habermas procura uma estratégia nova para enfrentar essas questões: a vinculação da pragmática transcendental ao que ele denomina de "naturalismo fraco" que vai levar a um primado genético da natureza em relação à cultura e garantir uma postura realista. Na realidade se trata, a partir de própria concepção habermasiana de metafísica, de uma proposta de vinculação entre pragmática transcendental e metafísica. $\mathrm{O}$ artigo procura mostrar o caráter problemático desta proposta.

Palavras-chave: Habermas. Filosofia transcendental. Filosofia contemporânea.

\section{HOW HABERMAS SETS HIMSELF IN THE SCENARIO OF CONTEMPORARY THOUGHT}

\begin{abstract}
Habermas raises the claim to rethink transcendental philosophy from the linguistic turn and to articulate philosophy as a "Kantian pragmatism", placing at the center the primacy of the pragmatic dimension. In place of the transcendental subjectivity of consciousness, the "transcendentalized intersubjectivity" of the world of life is replaced. This reveals a fundamental task of philosophy today: playing the role of "interpreter" between specialized cultures, science, technology, law and morality, and the communicative practices of everyday life. He is aware that the reinterpretation of the transcendental sphere as our daily intersubjective practices brought back precisely the problems that Kant intended to overcome with transcendental philosophy: relativism and skepticism. Habermas is looking for a new strategy to tackle these issues: linking transcendental pragmatics to what he calls "weak naturalism" that will lead to a genetic primacy of nature over culture and guarantee a realistic posture. In reality, from a Habermasian conception of metaphysics, it is a proposal to link transcendental pragmatics and metaphysics. The article seeks to show the problematic character of this proposal.
\end{abstract}

Keywords: Habermas. Transcendental philosophy. Contemporary philosophy.

1 Graduou-se em Filosofia pela Faculdade de Filosofia de Fortaleza (1962), mestrado em Teologia pela Pontifícia Universidade Gregoriana de Roma (1966) e doutorado em Filosofia pela Universidade Ludwig Maximilian de Munique (1971). Atualmente, é professor emérito da Universidade Federal do Ceará e atua como professor permanente do Programa de Pós-Graduação em Filosofia da UFC (Mestrado e Doutorado). Foi professor visitante na pós-graduação em Filosofia da Pontifícia Universidade Católica do Rio Grande do Sul e no CESEEP, em São Paulo. Orcid: http://orcid.org/00000003-1593-5573. E-mail: manfredo.oliveira2012@gmail.com. 
Um caminho, certamente profícuo, para compreender a posição filosófica assumida por Habermas é tentar ver como ele se situa em relação às correntes fundamentais do pensamento contemporâneo. Não se trata aqui, porém, de uma consideração de todo o vasto e diferenciado quadro da filosofia contemporânea, mas daquelas correntes que emergiram daquilo que Quine considera, depois de Hume, o evento teórico-metodológico mais importante e irreversível para a articulação de um empreendimento teórico: a virada linguística (QUINE W. Van Orman, 1981, 23). Considerar este debate significar compreender como Habermas na realidade está procurando mostrar a partir de onde, de que questões básicas, a partir de que desafios ele articulou sua própria posição.

\section{I) A questão da complementaridade das duas versões da virada linguística}

Para Habermas, o que está em jogo, acima de tudo na filosofia contemporânea, é a virada linguística da filosofia que se concretiza enquanto novo paradigma para a filosofia enquanto tal. Em seu caso, isso vai ocorrer através de uma consideração explícita do cenário filosófico que se efetivou após a virada linguística, que o conduziu a um "Pragmatismo Kantiano", ou seja, a uma reestruturação da filosofia transcendental a partir da mediação irrecusável da linguagem pondo no centro de tudo a primazia da dimensão pragmática. Isso significa, para a filosofia transcendental, a passagem da "consciência" para a "linguagem" como a esfera fundamental de mediação. Para o conhecimento, por exemplo, a consequência é que nós, enquanto sujeitos cognoscentes, já sempre nos situamos no horizonte de nossas práticas no mundo da vida. Isso mostra que linguagem e realidade se interpenetram numa forma que é indissolúvel para nós (HABERMAS J., Wahrheit und Rechtfertigung, 1999, 40-41). Assim: “Assumir a virada linguística e subordinar a teoria à prática são os aspectos positivos centrais de seu pensamento pós-metafísico" (PUNTEL L. B., O pensamento pós-metafísico de Habermas: uma crítica, 2013, 177).

Numa palavra, qualquer experiência, para Habermas, já é "filtrada" pela linguagem de modo que um acesso à realidade não mediado linguisticamente é simplesmente impossível para nós. Assim, a linguagem emerge aqui como condição irrecusável de todo acesso ao conhecimento válido de tal forma que não se pode mais considerar a experiência, totalmente independente de nossa linguagem, como a instância de controle de nossos conhecimentos já que a linguagem nos fornece os esquemas com que conhecemos qualquer coisa que conhecemos. Perde, então, qualquer sentido a "coisa 
em si" no sentido de Kant como algo que seria situado fora da mediação transcendental. Desta forma, "linguagem e realidade estão mutuamente imbricados de tal modo que toda experiência humana é linguisticamente impregnada" (OLIVEIRA M.A.O. de, É $a$ filosofia uma Pragmática?, 2010, 105).

A consequência central desta virada para a filosofia é que todas as suas questões só podem ser enfrentadas através de uma análise das estruturas da linguagem (HABERMAS J., Nachmetaphysisches Denken, 1988, 52-57). A tese central, então, desta rearticulação linguístico-pragmática da filosofia é: no lugar da subjetividade transcendental da consciência se põe a "intersubjetividade destranscendentalizada" do mundo da vida, o que tem enormes consequências para a articulação da filosofia, pois o conceito de mundo da vida é a categoria central de um empreendimento filosófico, pois "ele forma o horizonte para a prática do entendimento em que sujeitos, agindo comunicativamente, tentam tratar juntos de seus problemas quotidianos" (HABERMAS J., Wahrheit und Rechtfertigung, 1999, 326 ). "Ele descreve sua posição da seguinte maneira: a filosofia liberta-se do logocentrismo quando não é completamente absolvida pela autorreflexão das ciências, quando seu olhar não está fixado no sistema científico, quando reverte esta perspectiva e olha retrospectivamente para o emaranhado do mundo da vida. Descobre, então, que a razão já está operando na prática comunicativa quotidiana" (PUNTEL L.B., O pensamento pós-metafísico de Habermas: uma crítica, 2013, 182). Isso vai exigir que atribuamos às condições intersubjetivas de interpretação linguística e compreensão um papel transcendental, o que foi impossível para Kant uma vez que ele articulou o pensamento transcendental no "modelo mentalista".

Para Habermas, o mundo da vida é sempre intuitivamente presente para todos nós enquanto uma totalidade pré-teórica, que não é problematizada, nem objetivada, mas que, pelo poder subversivo da reflexão e da análise esclarecedora, crítica e dissecante, faz com que a filosofia possa se contrapor ao senso comum. Além disso essa relação com o mundo da vida revela uma tarefa fundamental da filosofia hoje: desempenhar o papel de "intérprete" entre as culturas especializadas da ciência, tecnologia, direito e moralidade, por um lado, e as práticas comunicativas da vida cotidiana por outro (HABERMAS J., Nachmetaphysisches Denken, 1988, 46).

Essa postura mostra que Habermas conserva a referência ao sujeito, agora entendido enquanto "intersubjetividade", como elemento decisivo para a articulação da filosofia. Ele articula, na realidade, uma nova vertente da filosofia moderna da subjetividade, mais precisamente através de uma concepção radicalmente transformada 
do conceito de transcendental uma vez que o transcendental perde a conotação de algo transcendente que pertence ao mundo inteligível e se transforma numa grandeza que pertence à terra, pois é o mundo de vida profano que assume o lugar transmundano do numenal. Daí porque Habermas fala aqui de uma "deflação do extra quotidiano". O pragmatismo conserva o quadro transcendental, porém relaxa a contraposição entre o transcendental e o empírico (HABERMAS J., Wahrheit und Rechtfertigung, 1999, 26, 27).

A descentralização habermasiana, contudo, não "descentraliza" a filosofia transcendental enquanto filosofia da subjetividade, isto é, não a supera, mas antes, como diz L. B. Puntel, articula uma alteração deste tipo de filosofia. Como o próprio Habermas afirma, a destranscendentalização implica uma alteração no conceito de transcendental no sentido de compreendê-lo no contexto da prática comunicativa quotidiana (HABERMAS J., Wahrheit und Rechtfertigung, 1999, 26).

Isto não implica, contudo, uma superação do quadro no qual Kant articulou o específico da filosofia. A filosofia tem para Kant como tarefa específica determinar o a priori do que pode ser conhecido, ou seja, legitimar os conhecimentos empíricos e, enquanto tal, ela põe uma reflexão epistemológica no centro da filosofia e se constitui como uma teoria transcendental, uma teoria das estruturas do sujeito enquanto possibilitadoras do conhecimento objetivamente válido dos fenômenos. Essa é razão pela qual Agazzi afirma que, no caso de Kant, "temos uma objetividade desprovida de qualquer dependência de qualquer objeto, mas baseada nas condições (transcendentais) do próprio processo cognitivo", o que significa para ele "deslocar o foco da reflexão do objeto para o sujeito" (AGAZZI E., A objetividade científica e seus contextos, 2000, 54, 70 , nota 63$)$.

O que Habermas chama de mundo é justamente a outra dimensão em relação à dimensão transcendental que agora é repensada como prática comunicativa quotidiana, ou seja, como mundo da vida. Isto revela que a dicotomia característica da filosofia transcendental, entre a esfera transcendental e seu outro, persiste aqui. Por isso, para Habermas, a diferenciação entre o mundo e o intramundano, defendida por Kant, deve ser preservada mesmo que o sujeito transcendental perca sua posição fora do tempo e do espaço e seja repensado enquanto multidão de sujeito capazes de linguagem e de ação (PUNTEL L.B., O pensamento pós-metafísico de Habermas: uma crítica, 2013, 206207). 
No entanto, Habermas tem consciência de que a passagem da esfera transcendental do mundo inteligível para nossas práticas intersubjetivas quotidianas, a releitura pragmática do transcendental, o que ele denomina de processo de "deflação" do modelo de filosofia transcendental articulado por Kant, trouxe de volta justamente os problemas que Kant pretendeu superar com sua forma de filosofia, a filosofia transcendental: o relativismo e o ceticismo. Habermas procura uma estratégia nova para enfrentar essas questões, contudo, sem pôr em questão a inevitabilidade da leitura pragmática do transcendental: a vinculação da pragmática transcendental ao que ele denomina de "naturalismo fraco", ou seja, um naturalismo não epistemológico, que vai levar a um primado genético da natureza em relação à cultura e garantir uma postura realista.

A partir daqui Habermas elabora um diagnóstico de sua maneira de interpretar o cenário filosófico contemporâneo e do desafio central da filosofia hoje: articular a vinculação do "primado epistêmico" do mundo linguístico centrado no mundo vivido com o "primado ontológico" de uma realidade independente da linguagem que impõe limitações às nossas práticas. Para ele, os grandes adversários de sua proposta são: por um lado, Quine, por reduzir todo conhecimento válido ao modelo de conhecimento das ciências empírico-analíticas desconhecendo, assim, a especificidade da compreensão de nossas práticas quotidianas em que está em jogo um autoentendimento normativo de sujeitos autônomos capazes de linguagem e ação e engajados em práticas comunicativas; por outro, Heidegger, por defender uma doação apriórica de sentido que Habermas interpreta como "fatalismo de sentido" uma vez que se impõe a nós destruindo nossa autonomia de seres racionais e com isto o espírito crítico.

Para Habermas, o naturalismo fraco, que ele propõe aqui, se radica numa única pressuposição metateórica: nossos processos de conhecimento, que se situam no quadro das formas de vida histórico-sociais, de alguma forma dão continuidade a processos de aprendizagem evolucionários prévios que produziram as estruturas de nossas formas de vida. Numa palavra, o mundo de vida humano é o fruto da evolução natural como o resultado de uma solução de problemas que conduziu a níveis cada vez mais complexos de desenvolvimento em níveis superiores de aprendizagem que vão cada vez resultando dos anteriores. Nesta ótica, as estruturas transcendentais, condições de possibilidade de nossos processos de conhecimento, manifestam-se como resultado de processos de aprendizagem de menor complexidade de natureza histórico-natural e 
justamente a partir disso adquirem seu conteúdo cognitivo (HABERMAS J., Wahrheit und Rechtfertigung, 1999, 37-38).

Este tipo de naturalismo, para Habermas, é uma postura que preserva a diferença transcendental entre o mundo e o que é intramundano apesar da destranscendentalização, ou seja, preserva a postura típica da filosofia transcendental (HABERMAS J., Wahrheit und Rechtfertigung, 1999, 370, e não produz nenhum tipo de reducionismo como é o caso do naturalismo forte que é incapaz de distinguir com clareza entre a "perspectiva interior" do mundo da vida e a "perspectiva exterior" do mundo objetivo trabalhada pelas ciências naturais (HABERMAS J., Wahrheit und Rechtfertigung, 1999, 38).

$\mathrm{Na}$ realidade, o que ele propõe, sem reconhecer explicitamente, é uma vinculação entre a filosofia transcendental, pragmaticamente reformulada, e uma postura metafísica - algo simplesmente inaceitável para a postura transcendental. A metafísica é entendida como uma teoria da realidade em seu todo. Como diz Agazzi, a metafísica, já no início de sua história oficial, ou seja, no pensamento de Aristóteles, "é concebida como 'ciência da realidade' como tal, isto é, das características mais universais da realidade..." A tarefa da metafísica, desde os gregos, consistiu em tematizar as condições gerais para a inteligibilidade da realidade e, neste sentido, ela é inevitável, pois qualquer um que comece a falar sobre algo deve tê-lo compreendido, o que pressupõe a compreensão de outras características mais gerais da realidade de tal modo que, neste sentido, é impossível não ter uma metafísica implícita (AGAZZI E., A objetividade científica e seus contextos, 2000, 486, 492).

Pode-se dizer, então, que Habermas chegou à explicitação de uma metafísica através de outros argumentos: a necessidade de superar o relativismo e o ceticismo e a justificação, num quadro transcendental, de uma postura realista. Assim, ele recusa um tipo de metafisica, a metafísica da tradição, sobretudo da metafísica moderna prékantiana, e constrói outro vinculado ao fisicalismo contemporâneo. Aqui há um conhecimento de objetos, o que viola o quadro teórico do pensamento transcendental, e, mais do que isto, ele propõe uma tese sobre a estrutura do mundo enquanto um todo, portanto invocando implicitamente uma dimensão oniabrangente: ele entende o todo da realidade como um "cosmo físico-biológico em evolução" o que significa elaborar uma metafísica segundo sua própria leitura de metafísica, cujo objetivo é articular um conhecimento do todo da realidade. Em sua interpretação da metafísica, a primeira característica da metafísica é justamente a pretensão de articular o que ele denomina 
"pensamento da identidade", ou seja, a articulação de uma "visão do todo", da unidade do uno e do múltiplo.

O uno e o múltiplo, concebidos abstratamente como relação de identidade e diferença, constituem a relação fundamental que o pensamento metafísico compreende, tanto como lógica como ontológica: o uno é ambos, tanto axioma como fundamento essencial, princípio e origem. Dele se deriva o múltiplo no sentido tanto de fundamentação como de origem. E graças a esta origem, o múltiplo é reproduzido como uma multiplicidade ordenada (HABERMAS J, Nachmetaphysisches Denken, 1988, 37).

Puntel considera essa postura como uma clara superação do quadro teórico da filosofia transcendental e isto se manifesta na medida em que se pergunta com que tipo de operador trabalha Habermas aqui: "Habermas está usando aqui um operador teórico irrestrito: ele não está pressupondo e usando o operador pragmático restrito... Aqui ele está falando de um nível teórico mais elevado, mais exatamente de um ponto de vista teórico irrestrito (PUNTEL L.B., O pensamento pós-metafísico de Habermas: uma crítica, 2013, 214). Não há, contudo, em Habermas, uma reflexão explícita que reconheça que esta forma de falar não é mais compreensível a partir da perspectiva pragmática do mundo da vida, cujas sentenças pressupõem um operador teórico restrito: "Desde a perspectiva das necessidades e ideias dos sujeitos humanos no seu mundo da vida é o caso que", que é, como mostra Puntel, um operador muito restrito. "O naturalismo tanto fraco como forte são posições irrestritamente universais a respeito da relação entre o mundo da vida e o mundo natural" (PUNTEL L.B., O pensamento pós-metafísico de Habermas: uma crítica, 2013, 211). Habermas não pensa as implicações do que ele realmente faz para a articulação de uma teoria filosófica já que seu objetivo explícito é assumir um naturalismo que preserve a diferença transcendental.

A virada linguística na filosofia se articulou em duas variantes, a analítica e a hermenêutica, que para Habermas são mutuamente complementares apesar de terem se desenvolvido como propostas mutuamente incompatíveis. A sua fundamental complementariedade se articulou de maneira clara no pensamento de Humboldt que de certa maneira articulou um rumo paradigmático para o enfrentamento das questões que são desafiadoras para a articulação da filosofia no mundo contemporâneo (HABERMAS J., Wahrheit und Rechtfertigung, 1999, 67 e ss.).

\section{II) Significação filosófica da teoria da linguagem de Humboldt}


Habermas parte, em sua apresentação do pensamento de Humboldt, da distinção entre três funções fundamentais da linguagem: a) A função cognitiva de formar pensamentos e expressar fatos; b) A função expressiva de exprimir sentimentos e provocar sensações; c) A função comunicativa de transmitir algo, levantar objeções e produzir acordos. A combinação destas três funções ocorre de maneira diferente no nível semântico e no nível pragmático: no nível semântico, a concentração é na visão linguística de mundo; no nível pragmático, no diálogo.

a) O ser humano, para Humboldt, pensa, sente e vive somente na linguagem e é formado por ela. As linguagens são órgãos das formas peculiares de pensamento e sentimento das nações, pois elas articulam um todo de conceitos fundamentais e modos de concepção em que se articula uma concepção prévia de tudo o que os membros de uma comunidade linguística encontram, ou seja, linguagem e realidade se interpenetram, assim que não há qualquer acesso imediato a uma realidade não linguisticamente interpretada. A realidade é de antemão situada num horizonte específico de sentido. Ele articula uma conexão inseparável entre a forma interna de uma linguagem e uma visão determinada de mundo. Por meio da semântica, a linguagem estrutura também a forma de vida de uma comunidade linguística.

Para Habermas, esta forma de compreensão da linguagem rompe com quatro características básicas da filosofia da linguagem que se articulou desde Platão até Locke e Condillac. Em primeiro lugar, articulando uma concepção holística da linguagem, rompeu com o que hoje se chama uma semântica composicional segunda a qual o significado de uma sentença se efetiva a partir da composição dos significados dos componentes subsentenciais. Segundo, a linguagem não é mais vista, em primeiro lugar, a partir de sua função cognitiva de representar objetos e fatos, mas é o medium do espírito de um povo. Terceiro, esta concepção torna inaceitável uma concepção instrumentalista de linguagem e comunicação. Quarto, a linguagem não é a propriedade privada de um indivíduo, mas gera uma conexão de sentido intersubjetivamente partilhado em expressões culturais e práticas sociais.

b) Enquanto recipiente do espírito objetivo, a linguagem transcende o espírito subjetivo e possui autonomia frente a ele. Aqui se manifesta o poder das tradições que agem sobre as gerações de tal modo que se dá uma interação entre subjetividade e objetividade. Com isto, revela-se ao mesmo tempo um poder do ser humano sobre a linguagem e um poder da linguagem sobre os seres humanos. Contudo, embora diferentes linguagens produzam diferentes visões de mundo, o mundo mesmo aparece a todos os 
falantes enquanto um e o mesmo. Como é isto possível? Esta é uma pergunta que vem sendo discutida desde o início do século XIX. Esta concepção de linguagem levanta para Habermas um problema muito sério para a forma como Kant articulou a filosofia transcendental: se as visões de mundo das diferentes comunidades linguísticas constituem o a priori de sentido que torna possível nosso conhecimento dos objetos do mundo, então este a priori é arbitrário e também a posteriori, embora necessário e irrecusável. Desta forma, perde-se a validade universal de um a priori transcendental como Kant o pensou.

c) Para Habermas, Humboldt articulou uma mútua complementaridade entre semântica e pragmática da linguagem: ele se preocupou tanto com o particularismo de mundo linguisticamente aberto de uma nação, portanto com a particularidade de uma forma de vida, quanto ele considerou a função cognitiva da linguagem não unicamente sob a ótica semântica. Há para ele uma divisão de trabalho entre a semântica das visões de mundo linguísticas e uma pragmática formal do diálogo. Algo é sempre enfocado a partir de uma determinada visão de mundo, mas no uso pragmático da fala manifesta-se uma tendência contraposta ao particularismo semântico. No diálogo, os participantes querem compreender-se mutuamente, mas ao mesmo tempo se entenderem sobre algo, ou seja, querem, enquanto possível, chegar a um consenso. Isto se aplica também à compreensão para além das fronteiras das comunidades linguísticas, como se mostra, por exemplo, nas traduções de uma comunidade linguística para outra.

No enfrentamento desta questão, Humboldt postula um ponto de vista mais alto que permita uma assimilação mútua em relação a uma mesma coisa sobre que se pretende chegar a um entendimento numa antecipação formal deste terceiro ponto de vista. Assim, é numa tal interação do uso comunicativo com a função cognitiva da linguagem que ambas as partes têm que se relacionar, cada uma a partir de sua própria perspectiva, com um ponto de vista comum de convergência do mundo objetivo para tornar compreensível uma linguagem desconhecida. Diferentes encontram uma linguagem comum e aprendem a se entender na medida em que discutem sobre as mesmas coisas. Nós só compreendemos expressões linguísticas na medida em que conhecemos as circunstâncias em que elas contribuem para a compreensão sobre algo no mundo. Uma visão comum da realidade enquanto uma região situada no meio entre visões do mundo de diferentes linguagens é uma pressuposição necessária para diálogos com sentido.

No discurso, uma visão de mundo deve, através da contradição dos outros, de tal modo ser questionada que os horizontes de sentido dos participantes possam ser alargados através do descentramento progressivo de cada perspectiva própria, o que só 
pode ocorrer quando é possível mostrar um potencial crítico nos pressupostos pragmáticos dos diálogos. Humboldt mostra sua existência através de uma análise do sistema de pronomes pessoais. Em seu uso, Humboldt detecta um dualismo inalterável fundado na própria situação do discurso: todo falar é baseado na direção da palavra e na resposta. Desta estrutura dialética do discurso emerge um espaço público que gera um mundo vivido intersubjetivamente partilhado, um ser social atual que cria intersubjetividade e objetividade, condição necessária da objetividade do pensamento. Aprendemos do mundo quando aprendemos uns dos outros, ou seja, essa intersubjetividade do entendimento gerada no discurso e no contra discurso é igualmente uma condição necessária para a objetividade do pensamento. Mas na resposta de uma segunda pessoa à fala de alguém há não só a força da integração social da resposta afirmativa, mas também a força de comprovação crítica da contradição.

Numa palavra, a posição de Humboldt se caracteriza fundamentalmente por articular uma interação pragmática da função cognitiva com a função comunicativa da linguagem. Para ele isto tem grande significação para a humanidade, pois na medida em que as visões específicas de mundo se alargam, relativizam-se também as orientações valorativas de tal modo que se põe para a humanidade a tarefa de superar as fronteiras que geram preconceitos e visões unilaterais de todo tipo e o esforço de tratar a humanidade toda sem consideração de religião, nação e cor, como uma única grande tribo de irmãos, ou seja, trata-se da proposta de vincular abertura hermenêutica e moral igualitária.

A partir da perspectiva semântica, Humboldt diferencia o conceito transcendental de uma espontaneidade "formadora de mundo" em dois aspectos: a esfera dos padrões de interpretação cultural e a esfera das práticas sociais. No aspecto cognitivo, a linguagem articula um pré-compreensão de mundo compartilhada intersubjetivamente pela comunidade e com isso gera um pano de fundo não problemático de interpretação dos eventos do mundo. Praticamente, a linguagem marca o caráter e a forma de vida das comunidades. Do ponto de vista pragmático, Humboldt trabalha a questão das estruturas universais da fala. Neste nível se revelam o papel, as posições e as relações interpessoais dos participantes. Aqui duas questões são fundamentais: se os participantes querem entender-se sobre eventos do mundo objetivo ou sobre pretensões normativas ou sobre orientações valorativas. Para Habermas se articula em Humboldt uma arquitetônica da filosofia da linguagem que continua decisiva para uma transformação pragmática da 
filosofia de Kant, o que para ele constitui o desafio fundamental do pensamento contemporâneo.

\section{III) O desenvolvimento das duas versões da virada linguística enquanto ruptura com a complementaridade}

Habermas interpreta a situação do desenvolvimento das duas versões da virada linguística, a analítica e a hermenêutica, como uma ruptura com a proposta articulada por Humboldt, num primeiro momento por elas se entenderem em contraposição radical uma contra a outra. Assim, por exemplo, a proposta hermenêutica é marcada pela não consideração da dimensão expositiva da linguagem, uma vez que não analisa de maneira convincente as condições de referência e verdade das sentenças. Isto revela uma continuidade com o déficit do humanismo da renascença que separou a retórica e a gramática da lógica, criando uma desconfiança em relação à lógica por esta abstrair as sentenças dos atos de proferimento e dos contextos de fala. Frege, por outro lado, o da proposta analítica, vai concentrar-se totalmente na dimensão expositiva da linguagem apesar de suas interessantes observações sobre a força assertórica da linguagem. Frege se limita, então, à análise lógica da forma de sentenças simples e deixa a dimensão comunicativa a uma consideração empírica.

A questão não é, porém, tão simples assim como nesta contraposição clara entre as duas posturas, porque para Habermas a falta de complementaridade dos dois aspectos da linguagem ocorre também no interior de cada uma delas, porque ambas as posturas, por exemplo, partindo de posições contrapostas, limitam-se à semântica da linguagem. O exemplo mais claro aqui é o de Heidegger, que articulou uma fenomenologia hermenêutica, mas se concentrou na dimensão semântica de Humboldt. Ele parte da abertura de mundo da linguagem, mas se concentra na análise semântica das estruturas conceituais básicas e das conexões de sentido que habitam na forma da linguagem enquanto tal. Isto significa dizer que ambas as posições defendem o primado da semântica sobre a pragmática.

Habermas faz depois uma comparação destas versões com Humboldt para detectar avanços e perdas.

1) Para Humboldt, a compreensão de uma expressão linguística ocorre quando se sabe sob que condições ela pode ser empregada com a finalidade de compreensão de algo no mundo. Somente Frege explicou a conexão interna entre significado e validade no nível de sentenças assertóricas simples. Ele efetiva uma

\begin{tabular}{|c|c|c|c|c|}
\hline Qovista Dialectus & Ano 10 & n. 24 & Setembro - Dezembro 2021 & p. $131-163$ \\
\hline
\end{tabular}


reviravolta no que diz respeito à concepção de linguagem na tradição vinda dos gregos na medida em que considera a expressão linguística fundamental não a palavra, mas a sentença que pode ser verdadeira ou falsa, o que significa considerar a verdade como conceito semântico fundamental para a explicação do sentido das expressões linguísticas. As condições sob as quais uma sentença é verdadeira determinam o sentido de uma sentença. Isso trouxe consequências importantes: abriu-se a possibilidade de superar a semântica composicional e com isso a possibilidade de articulação de uma nova semântica, a partir do que Dummett depois vai chamar de "princípio do contexto": uma palavra só tem sentido a partir de sua contribuição para o sentido de uma sentença, ou seja, as expressões linguísticas estão associadas uma com as outras através de um rede complexa de linhas semânticas. Habermas silencia aqui a respeito de uma nova ontologia como possibilidade aberta a partir da articulação de uma semântica contextual; b) Superase a partir daqui a ideia tradicional de que os símbolos linguísticos são nomes de objetos. Frege analisa sentenças através do modelo matemático das funções e com isto ele mostra como dois diferentes atos se interligam: a predicação de propriedades e a referência a objetos a que propriedades são atribuídas.

Distinguindo sentido e referência, Frege mostra como é possível referir-se ao mesmo objeto a partir de diferentes descrições. Sentido, referência e verdade são os conceitos fundamentais para trabalhar a função expositiva da linguagem e sua relação ao mundo, o que a seu modo vai ser retomado por Wittgenstein no Tractatus. Para a filosofia enquanto tal, a questão que perpassa fundamentalmente estas propostas filosóficas é a de uma mudança radical de paradigma que se dá aqui: a substituição do paradigma da consciência pelo paradigma da linguagem que elimina a postura mentalista da filosofia. Também aqui Habermas silencia sobre a retomada desta perspectiva na "filosofia da mente" da atualidade que repõe o pensamento no lugar da linguagem como elemento básico de uma teoria filosófica (AIUB M./GONZALEZ M.E.Q./BOENS M.C. (orgs.), Filosofia da Mente, ciência cognitiva e o pós-humano: par onde vamos? 2015), como também sobre a chamada "virada especulativa" de ontólogos contemporâneos que rejeitam a virada linguística da filosofia (BRYANT L./SRNICEK N./HARMAN G. (orgs.), The Speculative Turn, 2011).

2) Através de outros caminhos, Heidegger articula uma crítica semelhante à filosofia da consciência. Sem levar em consideração a filosofia da linguagem, ele apresenta em primeiro lugar uma análise existencial do ser humano em que ele vincula de forma original Dilthey e Husserl. Dilthey teve na realidade uma posição 
epistemológica: seu objetivo foi distinguir a metodologia de trabalho das "ciências do espírito" (as ciências que trabalham com a compreensão de sentido incorporado nas expressões simbólicas das tradições culturais e das instituições sociais) da metodologia de trabalho das explicações nomológicas dos eventos empíricos das "ciências naturais". Heidegger não se preocupa com questões epistemológicas e trata a compreensão como uma característica básica do ser humano que compreende sempre seu mundo e a si mesmo nele inserido. Assim, o objetivo fundamental de "Ser e Tempo" é tematizar a estrutura desta compreensão prévia de si, de si mesmo e do ser.

Para realizar seu objetivo, Heidegger transforma o modelo fenomenológico de descrição das percepções de Husserl no modelo hermenêutico da interpretação de textos, só que o olhar da fenomenologia hermenêutica não se dirige em primeiro lugar ao conteúdo manifesto de um proferimento, mas ao contexto que acompanha sua execução. Heidegger faz uma distinção que tem grandes consequências para a articulação de sua filosofia: a distinção entre o nível predicativo (o nível das sentenças que constituem a linguagem) e o nível hermenêutico, o nível do dar-se, do desvelar-se do ser. Desta forma, há um dizer mais originário, pré-conceitual, pré-sentencial, pré-teórico (hermenêutico), do que o da objetividade das sentenças. Aqui o hermenêutico tem primazia frente ao proposicional (saber predicativo), ou seja, o desvelamento do sentido fundamental enquanto conhecimento prévio e implícito do mundo é anterior a qualquer conhecimento sentencial. Desta forma, decide sobre o saber a respeito dos objetos do mundo um "fato" transcendental de desvelamento do mundo que em si mesmo não é nem verdadeiro nem falso, mas simplesmente acontece.

Consequentemente, para Habermas, desaparece propriamente a semântica da verdade. Na realidade, a fenomenologia hermenêutica desconhece o direito próprio da função cognitiva da linguagem e o sentido próprio da estrutura das sentenças - o que leva Heidegger a eliminar a interação entre linguagem e saber do mundo. Com isto ele concede à semântica das visões linguísticas de mundo uma primazia irrestrita frente à pragmática dos processos de compreensão. Por esta razão, frente a Humboldt desloca-se o lugar de controle do desempenho dos participantes do discurso para os eventos da abertura linguística do mundo. A linguagem é interpretada como uma escuta do ser e desta forma o ouvir tem primazia sobre o falar (HEDEGGER M., Unterwegs zur Sprache, 1989, 254).

Wittgenstein, para Habermas, de uma forma menos mistificadora, chega à mesma conclusão na virada pragmática da semântica da verdade à teoria do uso das expressões linguísticas. As expressões linguísticas têm funções múltiplas e diferentes nos 
diferentes contextos. Por isso, não tem o menor sentido perguntar pela essência da linguagem, mas o que é importante é observar como a linguagem funciona, ou seja, seu conhecimento só pode ser uma descrição a posteriori (método de descrição de fenômenos reais). Trata-se de mostrar como a linguagem realmente trabalha evitando os malentendidos que constituem a fonte dos problemas filosóficos. Trata-se de substituir uma explicação por uma descrição. Assim, os problemas filosóficos devem desaparecer completamente (PU \& 133). Desaparece, para Habermas, aqui completamente a diferença entre a questão da validade e a validade social. O filósofo se torna um observador de hábitos linguísticos e qualquer postura crítica desparece da filosofia.

\section{IV) Uma terceira corrente no cenário filosófico contemporâneo}

Habermas identifica uma terceira corrente filosófica no pensamento contemporâneo de que fazem parte pensadores de posições tão diferenciadas como Putnam, Dummett e Apel. O que é comum entre eles é assumirem a mudança paradigmática da consciência para a linguagem sem assumir o alinhamento cultural da verdade a um simples considerar como verdadeiro. Aqui se constituem duas tendências: a primeira se contrapõe à redução da virada linguística a uma simples consideração do tratamento das questões levantadas por Hume e Kant com novos meios (RORTY R., Der Spiegel der Natur, 1981, 287); a segunda, põe-se contra um particularismo semântico anti-iluminista que despreza a autocompreensão racional de sujeitos capazes de falar e agir enquanto seres racionais (BRANDOM R., Making it Explicit, 1994, 5).

Esta dupla tendência já caracteriza o assim chamado trabalho de habilitação à universidade alemã escrito por ele no fim dos anos cinquenta. Apel se posiciona aqui contra duas tendências vigentes na época: uma compreensão intencionalista do significado linguístico e uma compreensão instrumental da comunicação linguística. Por outro lado, alerta contra uma disjunção entre a função da abertura linguística do mundo e a função cognitiva de exposição dos fatos, defendendo uma interação e uma interpenetração mútua entre um projeto particular de significado e uma proposta de pensamento simplesmente universal orientando-se na arquitetônica kantiana do entendimento e da razão. A razão corresponde ao a priori semântico das visões de mundo que, porém, somente através do entendimento, ou seja, através do controle e do sucesso da ação racional recebe um lugar na sociedade. Com isso se efetiva uma mediação entre sentido e práxis. 
M. Dummett, por sua vez, põe-se diante do mesmo problema a partir de um pano de fundo completamente diferente. Ele assume as teses de Wittgenstein de que jogos de linguagem constituem horizontes de sentido intersubjetivamente compartilhados e estruturam formas culturais de vida. Rejeita, porém, a teoria do significado enquanto uso por ela eliminar a dimensão cognitiva da linguagem. Em seu lugar, ele articula uma semântica da verdade epistemicamente orientada para a validade. Sendo uma sentença expressão de suas condições de verdade, sua compreensão exige o conhecimento dessas condições e isto se radica em razões que nos dizem porque essas condições se cumprem.

Neste contexto, tem um lugar importante, para Dummett, a práxis da justificação, ou seja, o jogo da argumentação, ou seja, o jogo do justificar ou refutar (DUMMETT M., Language and Communication, 1993, 182), uma questão que para Habermas é simplesmente central na elaboração de sua própria perspectiva, pois se o filósofo pode descobrir, libertando-se do logocentrismo, que a razão já está operando na prática comunicativa quotidiana, no entanto pretensões de verdade, justiça normativa e sinceridade subjetiva, "como pretensões criticáveis, elas também transcendem os vários contextos nos quais são formuladas e ganham aceitação. No espectro de validade da prática quotidiana de alcançar entendimento, vem à luz uma racionalidade comunicativa a que se abre em várias dimensões" (PUNTEL L.B., O pensamento pós-metafísico de Habermas: uma crítica, 2013, 182-183).

Habermas elabora, a partir deste cenário, os desafios provenientes para a filosofia considerando um grupo de quatro questões centrais.

a) Análise da compreensão de sentido na hermenêutica gadameriana

Para Habermas, Gadamer fez uma mudança fundamental em relação à postura de Heidegger: ele não analisa o sentido da compreensão semanticamente a partir da abertura linguística de mundo, mas pragmaticamente a partir do entendimento entre autor e intérprete, ou seja., ele analisa a práxis da interpretação de textos canônicos a partir da lógica do diálogo de pergunta/resposta. O diálogo é apresentado por Gadamer como modelo de compreensão entre participantes que se entendem mutuamente sobre algo. Aqui se interpenetram a intersubjetividade de um mundo de vida compartilhado com a relação a algo no mundo objetivo, o que gera uma conexão interna entre sentido e possível verdade do que é dito. 
À primeira vista, tem-se a impressão de que Gadamer com a dimensão comunicativa da linguagem reabilita a promessa universal da razão. Essa dinâmica do entendimento mútuo se desenvolve nas trilhas da lógica de uma compreensão da coisa mesma. No entanto, Gadamer tira disto consequências opostas às de Humboldt. Como no caso de Heidegger, aqui esta referência à coisa acontece a partir de um consenso prévio gerado por tradições comuns.

Quais são, afinal, os motivos que guiam o empreendimento de Gadamer? Gadamer desenvolve sua hermenêutica enquanto reposta ao "problema do historicismo" e isto significa para ele opor-se ao objetivismo vigente nas ciências do espírito que separava o conhecimento das grandes tradições históricas do contexto privando-as de seu potencial de estímulo, neutralizando com isto sua força formadora. Ele se orienta na apropriação hermenêutica de obras clássicas da literatura, da arte e da religião e, sobretudo, de tradições dogmáticas, por exemplo, de textos jurídicos. A pré-compreensão, que o intérprete traz para seu trabalho, já é ela mesma fruto do que Gadamer denomina "história continuamente influente".

Trata-se, na realidade, de um agir do passado sobre nós, ou seja, da história que opera em nossa vida sem que possamos simplesmente dispor sobre ela. Daí porque o processo de interpretação, que implica no texto a correção da pré-compreensão e a precisão progressiva da compreensão com um diálogo virtual com o autor, só é possível no seio de uma conexão de tradição comum que abarca ambas as dimensões. O que caracteriza fundamentalmente, então, o cerne da hermenêutica de Gadamer é que ela se entende como continuação de uma tradição sem retê-la através de uma apropriação reflexiva ou prejudicar seu caráter obrigatório. Sem dúvida, para Habermas, o conhecimento se radica em condições fáticas, contingentes, que constituem condições históricas do trabalho do pensamento, o que impossibilita a determinação de um ponto arquimédico de fundamentação do pensamento.

O específico da reflexão, contudo, é justamente pôr em questão essa facticidade de normas herdadas de pensar e agir na sua obrigatoriedade. Em Gadamer, justamente porque a hermenêutica tem essencialmente a tarefa conservadora de uma autocompreensão ética de uma comunidade de tradição, assimilar seu método às sentenças das ciências é um engano fatal. Por isso, Gadamer substitui a velha ideia de compreender um autor melhor do que ele compreendeu a si mesmo simplesmente por um compreender de forma diferente. Esta é a razão que vai levar Apel, segundo Habermas, a dizer que Gadamer eliminou a pergunta pela validade da compreensão e por isso aqui a

\begin{tabular}{|c|c|c|c|c|}
\hline QRovista Dialectus & Ano 10 & n. 24 & Setembro - Dezembro 2021 & p. $131-163$ \\
\hline
\end{tabular}


reflexão crítica perde seu papel fundamental de romper com o poder de forças dogmáticas.

A interpretação habermasiana da Hermenêutica de Gadamer é fundamentalmente epistemológica como se sua pretensão fosse continuar a tradição que vem de Schleiermacher e Dilthey sobre a especificidade das ciências do espírito, mas isto se contrapõe radicalmente ao que Gadamer defende com muita clareza já em sua obra fundamental. Para ele, a hermenêutica articula uma compreensão da filosofia que desloca a questão central da filosofia, como em Hegel, da teoria do conhecimento para a ontologia. Ela supera tanto a "metafísica da substância" (metafísica clássica) e quanto a "filosofia da subjetividade" (filosofia transcendental) (GADAMER H-G., Wharheit und Methode, 459). Assim, ele não entende a Hermenêutica como uma questão metodológica (metodologia das ciências do espírito), mas como um aspecto universal da filosofia. Trata-se, assim, de uma nova articulação da filosofia enquanto tal (GADAMER H-G., Wharheit und Methode, 4512. O objeto da pesquisa não é o que fazemos ou devemos fazer, mas o que ocorre conosco para além do nosso querer e do nosso fazer (GADAMER H-G., Wharheit und Methode, XVI).

Essa proposta implica um confronto com a tradição e com o conceito de verdade vigente nas ciências modernas. Trata-se de uma experiência de verdade que transcende a esfera do controle da metodologia das ciências (GADAMER H-G., Wharheit und Methode, XXVII, XXVIII). Ele pretende articular um conceito de verdade que corresponda ao todo de nossa experiência hermenêutica, uma vez que a Hermenêutica tem a ver com o todo de nossa experiência do mundo. Que é, então, a experiência hermenêutica? Para mostrar isso, Gadamer tomou como exemplo a experiência da arte (FLICKINGER H-G., Da experiência da arte à hermenêutica filosófica, 2000, 27-52). A arte transcende o campo do mundo enquanto conhecimento metódico determinado pela subjetividade e, enquanto tal, é uma forma diferente de apresentação da verdade revelando os limites das ciências modernas. A obra de arte transcende o horizonte subjetivo tanto do artista como do expectador. "A obra de arte é um convite insistente a que nos deixemos sugar para dentro do espaço de um mundo novo, alheio" (FLICKINGER H-G., Da experiência da arte à hermenêutica filosófica, 2000, 33).

Ora, a hermenêutica aponta para a compreensão enquanto evento, uma experiência de verdade imediata, irrecusável e evidente. Isso suscita uma pergunta fundamental: que experiência de verdade é capaz de justificar filosoficamente tanto o 
conhecimento científico como as formas não científicas de conhecimento? O que está em jogo aqui é a explicitação do fundamento pré-reflexivo de todo saber objetivo.

Não existe fala sem sujeito, mas nossa fala é antes um receber: a essência da linguagem consiste em deixar emergir os entes no ser. Assim, a ontologia hermenêutica é um pôr-se à escuta do ser que abre espaço para a práxis histórica do ser humano. Desta forma, a hermenêutica herda de Heidegger a tarefa de situar a filosofia no espaço anterior à sentença (GRONDIN J., Hermeneutische Wahrheit?, 1994, 94). A dimensão propriamente hermenêutica da linguagem é uma dimensão mais originária do que a dimensão predicativa. Ela tematiza a esfera que subjaz à totalidade da experiência do mundo e à sua práxis. No entanto, é na palavra que ela se apresenta. Daí a afirmação central de Gadamer: "ser que pode ser compreendido é linguagem" (GADAMER H-G., Wharheit und Methode, 450).

O evento linguístico é um evento finito: o horizonte atual não inclui toda a verdade, pois é sempre um horizonte específico. A hermenêutica não conduz a um saber absoluto, pleno e completo assim que toda declaração sobre o mundo contém sempre o dito e o não dito: o ser é revelado e oculto pela linguagem (GADAMER H-G., Wharheit und Methode, 451). A hermenêutica se revela, então, como a metafísica que o ser finito e histórico pode fazer, a metafísica da historicidade e da finitude. Seu núcleo é o mútuo pertencer da palavra e da coisa. Toda palavra irrompe do centro da linguagem e tem um relacionamento com o todo de modo que todo falar humano é finito justamente por nele jazer uma infinitude de sentido a ser desenvolvida e interpretada que Gadamer chama de “dimensão especulativa da linguagem": cada palavra se relaciona a partir de si mesma com um todo (GADAMER H-G., Wharheit und Methode, 450).

A compreensão em Gadamer não é pensada como uma atuação do sujeito, mas como o inserir-se num evento de tradição no qual passado e persente se medeiam constantemente (GADAMER H-G., Wharheit und Methode, 274-275), pois sem o passado não se forma o horizonte do presente. Para Gadamer, isso significa uma reabilitação frente ao iluminismo da autoridade e da tradição, o que não implica aceitálas cegamente, ou seja, a autoridade das pessoas não tem sua razão última num ato de submissão e abdicação da razão, mas num ato de reconhecimento e conhecimento de que o outro está de posse de um juízo e compreensão superiores (GADAMER H-G., Wharheit und Methode, 263), ou seja, temos que pôr constantemente nossos pré-juízos à prova. Com que critérios se faz isso? Com que justificação posso afirmar que a compreensão do outro é superior? A ideia do pensar fundamentalmente como um "ver" da tradição 
fenomenológica continua aqui decisivamente e sem dúvida é um déficit teórico muito sério, como Habermas apontou, compreendido, porém, não dentro de uma continuação da epistemologia das ciências do espírito, mas no seio da proposta de uma fenomenologia hermenêutica enquanto metafísica da finitude.

b) A questão da dimensão cognitiva da linguagem: a proposta de Apel a partir de Peirce.

Para Habermas, essa discussão tem interesse enquanto conduziu à articulação de um projeto de reestruturação da filosofia transcendental enquanto Hermenêutica Transcendental em Apel e respectivamente enquanto Pragmática Formal em seu próprio pensamento. Apel vai enfrentar a questão do pluralismo de visões de mundo, supostamente incomensuráveis, com a distinção de duas estratégias teóricas. Ele distingue o a priori semântico de sentido das visões linguísticas de mundo, que são plurais, da constituição de campos de objetos das ciências da natureza e das ciências do espírito (ciências do sentido) que integra estruturas universais da ação com propósito racional e a interação. Trata-se aqui de um a priori pragmático que determina tanto os objetos da experiência possível quanto o sentido categorial de sentenças que dizem respeito a coisas e eventos e a pessoas, seus proferimentos e contextos.

Num segundo momento, ele distingue entre dois tipos de a priori - o que é decisivo para a tomada de posição frente à hermenêutica fenomenológica: o a priori da "experiência", de que se falou antes, e o a priori da "argumentação" na forma de pressupostos pragmáticos universais nos quais pretensões de verdade são submetidas à prova. Isto já significa uma configuração da filosofia transcendental que vai além da proposta por Kant na medida em que ele distingue entre a constituição de objetos e reflexão de validade: uma coisa são condições pragmáticas da objetividade de experiências possíveis, outra são as condições de comunicação para a solução discursiva de pretensões de verdade, ou seja, de uma busca cooperativa de verdade, distinção que é fruto de uma interpretação pragmática de reflexão de validade profundamente marcada pelo pensamento de Ch. Peirce (CARMO L.A.D. do, Discurso filosófico e a arquitetônica da ética do discurso, 2011, 89-112).

Para Peirce, a comunidade de investigação se entende enquanto uma comunidade de comunicação em que os participantes se orientam pela verdade de enunciados falíveis o que implica que a verdade nada mais pode ser do que a expectativa de que afirmações até então bem fundadas possam ser incluídas num consenso final a ser 
alcançada no final dos dias. Numa palavra, a verdade é uma ideia reguladora, o que o leva a interpretar a comunidade como ilimitada e o processo de investigação como algo que se estende ao infinito. Uma filosofia transcendental assim compreendida tem como tarefa central uma reflexão sobre o sentido e da argumentação enquanto tal. Para Apel, segundo, Habermas, esta concepção teve a vantagem de juntar a tradição da analítica da linguagem com a tradição hermenêutica.

Essa ideia leva tanto a um conceito discursivo de verdade quanto à articulação de uma ética do discurso que propõe uma leitura intersubjetiva do imperativo categórico centrada numa concepção da moral focada nas perguntas pela justiça. Neste contexto teórico, a linguagem emerge como uma "grandeza transcendental", ou seja, condição necessária de possibilidade e validade da compreensão e do autoentendimento e com isso, consequentemente, do pensamento conceitual, do conhecimento de objetos e da ação com sentido.

O objetivo fundamental de Peirce, para Apel, foi renovar a questão de Kant das condições de possibilidade de juízos empíricos objetivos transformando-a em questão da possibilidade de uma compreensão intersubjetiva do sentido e da verdade das proposições e sistemas de proposições. Em Peirce, para Habermas (HABERMAS J., Da semântica formal à pragmática transcendental, 2020, 498 e ss.), toma o lugar do sujeito transcendental como sujeito do conhecimento a comunidade de pesquisadores que realizam experimentos para testar hipóteses. Tanto o teórico do conhecimento (trata da interpretação correta de experiências que precisam de explicação) quanto os pesquisadores (debatem sobre a interpretação de seus dados conseguidos a partir de hipóteses como também sobre teorias concorrentes a respeito das hipóteses) discutem sobre intepretações, de modo que a dinâmica do processo cognitivo reside no discurso sobre interpretações controversas.

No entanto, em distinção com Habermas, Apel situa esta transformação em Peirce no contexto do desenvolvimento da estrutura das ciências modernas e suas pretensões teóricas. Isto significa, em primeiro lugar, o fracasso da proposta de substituição da esfera transcendental de Kant, ou seja, da unidade transcendental da consciência enquanto condição de possibilidade e validade de nosso conhecimento empírico de objetos pela "Logic of Science" moderna. O objetivo aqui consistiu em substituir a esfera transcendental pela sintaxe lógica e pela semântica das linguagens da ciência. Essas linguagens da ciência enquanto "semantic framework" são o novo substrato das regras a priori em que se decide sobre uma possível descrição e explicação

\begin{tabular}{|c|c|c|c|c|}
\hline QRovista Dialectus & Ano 10 & n. 24 & Setembro - Dezembro 2021 & p. $131-163$ \\
\hline
\end{tabular}


das coisas enquanto elas formam uma conexão de acordo com leis. Desta forma estaria resolvido o problema kantiano da validade objetiva do conhecimento, tese desenvolvida segundo Apel pelo pensamento de R. Carnap.

As aporias deste modelo levantaram em Pierce, segundo Apel, a necessidade de repensar a filosofia transcendental de Kant do ponto de vista semiótico a partir das sugestões da filosofia da linguagem de Ch. Morris (APEL K-O, Transformation der Philosophie, Vol. 1, 1976, 157 e ss.; Der Denkweg von Charles S. Peirce, 1975). Uma consequência fundamental desta reformulação da postura transcendental no pensamento de Peirce vai ser, para Apel, a superação radical do solipsismo metodológico, presente em Descartes e Kant, na medida em que o conhecimento, na relação sujeito-objeto, já sempre pressupõe o "acordo sobre o sentido" que acontece no nível da relação sujeitosujeito. Desta forma, para Pierce, o acordo mútuo intersubjetivo constitui a condição de possibilidade e validade transcendental-hermenêutica de todo conhecimento objetivo, o que significa dizer que aqui a mediação intersubjetivo-linguística tem a centralidade. Com isso se esclarece ao mesmo tempo que a linguagem deixa de ser apenas um instrumento de comunicação de um conhecimento efetivado sem ela e passa a ser considerada mediação irrecusável do conhecimento. Portanto, em Peirce se dá uma passagem, de grandes consequências para a filosofia, da crítica do conhecimento enquanto análise da consciência para a análise da linguagem, e com isto se transforma radicalmente a questão da validade do conhecimento na medida em que sua solução não é mais a certeza para uma consciência solitária, mas a formação de um consenso intersubjetivo radicada numa compreensão linguístico-argumentativa.

Para Apel, no contexto desta reformulação do pensamento transcendental o conhecimento é profundamente repensado, pois sua crítica não tem mais a ver com princípios e regras de uma consciência isolada, mas antes de competências, produções regras e pressupostos fundantes para parceiros de uma comunidade de comunicação linguisticamente mediada. Numa palavra, agora se pensa a partir de uma mútua imbricação entre conhecimento e comunicação. Apel assume a tese fundamental de Peirce de que conhecimento é uma ação mediada por signos no contexto de sua tese de que um sinal é algo tridimensional: “é algo que designa algo para alguém”. É a partir daqui que Peirce vai substituir as noções de fenômeno e coisa em si, algo desconhecido por nós, pela distinção entre o real como algo em princípio cognoscível e o que de fato é conhecido aqui e agora. 
A partir deste fundo perceano, Apel vai articular uma reformulação da filosofia transcendental em profunda discordância com Habermas. Sem dúvida, ambos concordam que esta reformulação vai levar a um novo ponto de partida da filosofia: o mundo vivido, a base da vida concreta do ser humano efetivada através de relações intersubjetivas baseadas em certezas pré-reflexivas. Isto é o que Apel vai denominar o a priori da facticidade e constitui o ponto de partida irrecusável de uma reflexão filosófica. Esta reviravolta pragmática conduz a filosofia para uma questão central que para ele vai marcar uma profunda contraposição entre sua proposta de reformulação da filosofia transcendental e a proposta de Habermas: basta para a filosofia recorrer a este a priori da facticidade, ou seja, às fontes pragmáticas do mundo vivido, de tal modo que ela se possa articular como uma teoria reconstrutiva deste saber intuitivo, como pensa Habermas, ou tem ela de ir além dos pressupostos socioculturais das formas históricas de vida e assim recorrer, como ele propõe, a pressupostos necessários e irrecusáveis não apenas de fato que constituem as condições de possibilidade de toda forma de argumentação sensata?

A resposta a essa questão decide sobre a estrutura específica de uma teoria filosófica, pois na segunda alternativa o sujeito transcendental de Kant é agora a comunidade dos argumentantes e a filosofia é, em diferença com as teorias científicas, uma reflexão sobre as pretensões universais de validade da argumentação enquanto tal, ou seja, uma reflexão sobre os pressupostos não contingentes do conhecimento válido do contingente. A argumentação pressupõe, assim, uma comunidade real (o a priori da facticidade) e uma comunidade ideal de comunicação (o a priori do discurso).

Estas questões são para Apel decisivas em sua própria proposta de transformação da filosofia transcendental, porque isso significa que apesar da insuficiência da solução apresentada por Kant, a questão transcendental permanece incontornável e isso constitui o específico da filosofia frente às teorias científicas. Para Apel,

\footnotetext{
A postura de Habermas se radica precisamente em sua recusa a distinguir epistemológica e metodologicamente entre as possíveis sentenças das ciências sociais reconstrutivo-empíricas e as sentenças universais de validade a priori da filosofia, o que tem, como implicação imediata, a aplicação do princípio do falibilismo às próprias sentenças da pragmática universal filosófica, portanto, também, às sentenças sobre o princípio do falibilismo e das proposições necessárias da linguagem humana. Por esta razão, ele considera as condições necessárias de comunicação também contextuais, históricas e contingentes, consequentemente falíveis e sujeitas a uma acareação empírica, como as sentenças das ciências empíricas (OLIVEIRA M.A.O. de. Moral, Direito $e$ Democracia, 2004, 149-150).
} 
Por esta razão, Habermas aplica a tese do falibilismo também às sentenças da pragmática formal, o que significa dizer que ele considera as condições necessárias da comunicação como condições contextuais, históricas e contingentes, portanto falíveis e sujeitas a uma acareação empírica. A pergunta fundamental, para Apel, no que diz respeito à estruturação da filosofia é se "basta ao discurso filosófico confiar nestas fontes pragmáticas do dia-a-dia que são pressupostas por toda compreensão e constituem certezas faticamente isentas de dúvida e irrecusáveis do ponto de vista prático e assim se articular como uma teoria reconstrutiva destas certezas históricas"? Ora, para ele, a filosofia, para além destes pressupostos culturais das práticas humanas históricas, tem como tarefa demonstrar pressupostos de outro nível, ou seja, pressupostos necessários e irrecusáveis não apenas do ponto de vista fático, consequentemente não mais relativizáveis (OLIVEIRA M. A. O. de, 2004, 149).

Habermas conserva, então, o modelo transcendental de pensar, mas transforma sua estruturação. A primeira coisa a lembrar aqui é que a filosofia transcendental é uma filosofia exclusivamente do "A priori”, ou seja, ela não pensa objetos, mas a condição de possibilidade e validade de seu conhecimento. Um exemplo claro disso, em Habermas, é a proposta de uma ética transcendental enquanto ética do discurso. De que trata a filosofia? Não de objetos, mas de pressupostos inevitáveis de seu conhecimento. Desta forma, trata-se na ética do discurso da questão da moral e ele se preocupa em evitar mal-entendidos a respeito da estrutura do conhecimento filosófico que nele se articula enquanto uma filosofia transcendental-pragmática. A filosofia, enquanto conhecimento transcendental, busca demonstrar o princípio da moral. Esse princípio é puramente formal e, assim, radicalmente diferente de qualquer princípio de conteúdo ou de normas fundamentais. Não sendo o princípio moral fundamental de forma alguma um princípio de conteúdo, este princípio de nenhuma forma decide questões específicas de conteúdos.

Habermas denomina este princípio formal de princípio U que é o princípio pressuposto nas discussões concretas das pessoas a respeito das questões morais concretas de conteúdo. Para estas discussões, Habermas elabora um outro princípio que ele chama de princípio D: só podem levantar a pretensão de validade as normas capazes de aprovação pelos participantes de um discurso prático. Os níveis aqui são completamente diferentes e a filosofia se situa no nível U (onde não há conteúdos, mas um princípio a 
priori formal). No nível D, o filósofo pode participar da discussão sem dirigir o discurso. A ética do discurso é assim estritamente uma ética formal, ou seja, ela não fornece um conteúdo, mas um procedimento, um formalismo de procedimento e não uma ética material como a de Aristóteles, Tomás, etc. Não pode ser diferente se ele pensa de maneira transcendental que é um conhecimento restrito à articulação dos princípios do conhecimento e da ação válidos.

O que muda, então, em Habermas em relação à filosofia transcendental clássica? Muda radicalmente a esfera transcendental: ao invés de ser uma esfera do mundo inteligível, infalível e imutável, um outro mundo, portanto, a esfera transcendental é, na realidade agora, o conjunto das práticas comunicativas intersubjetivas. Continua sendo um A priori frente aos conteúdos concretos destas práticas, mas é um conteúdo histórico, pragmático, "inevitável apenas de fato" porque pode mudar completamente. Apesar de tudo continua sendo o pressuposto dos discursos concretos de conteúdo (HABERMAS J., Wahrheit und Rechtfertigung, 1999, 26).

Para Apel, Peirce distingue claramente, ao contrário de Habermas, entre o fundamento transcendental da objetividade da ciência, que é o específico da filosofia, e a possibilidade de corrigir empiricamente todas as proposições hipotéticas das ciências a partir de sua transformação pragmática. No entanto, para Apel, apesar desta distinção simplesmente decisiva para a reformulação do projeto transcendental, Peirce permanece cientificista na medida em que todo seu projeto é referenciado ao conhecimento experimental das ciências modernas. Neste sentido, Apel defende que o pragmatismo semiótico se estenda a tudo, portanto, também ao mundo humano e assim supere qualquer restrição cientificista.

Mesmo não nos situando numa postura transcendental, a diferença de quadro teórico entre filosofia e ciências é certamente fundamental para distinguir as tarefas específicas dos dois tipos de teoria e, sobretudo, nesta problemática fundamental, poder especificar o que compete propriamente a uma teoria filosófica.

Para Hösle, a obra principal de Habermas, a Teoria da Ação Comunicativa, é uma história abrangente da sociologia teórica e de sua própria teoria social. Ele pretende resolver dois problemas centrais para a sociologia hoje: o conceito de racionalidade e a mediação entre uma teoria da ação e uma teoria sistêmica que constituem as duas orientações teóricas básicas das teorias sociais em nosso tempo. Para ele, a única fonte de validade é a ação comunicativa que se efetiva no mundo da vida que ele contrapõe de uma maneira radical à formação dos sistemas como por exemplo o sistema econômico e 
sua administração burocrática sem considerar o fato de que, no mundo da vida, ambas as formas de comportamento interagem. $\mathrm{O}$ fato de Habermas haver posto sempre no centro de suas considerações as ciências sociais teve grandes consequências para seu conceito de filosofia, por exemplo, na recusa de uma separação nítida entre a priori e a posteriori, sua rejeição radical da metafísica hoje seriamente retomada na filosofia analítica, sua consideração da religião que se reduz à consideração de sua significação social sem uma reflexão filosófica sobre seu conteúdo (HÖSLE V., 2013, 298). Evidentemente, isso vai ter enormes consequências na articulação de uma proposta de filosofia.

c) A Teoria formal-pragmática do significado

O cerne de uma teoria da linguagem é uma teoria do significado, tomada essa expressão no sentido em que a entende a tradição analítica. Habermas pretende agora apresentar as suposições básicas de uma teoria formal-pragmática do significado.

1) A teoria dos atos de fala, articulada por Austin e Searle, é uma teoria adequada para situar a concepção fundamental da teoria do significado de Dummett (DUMMETT M., Language and Communication, 1993, 34-93) no contexto de uma teoria da ação comunicativa. Em primeiro lugar se põe a questão da conexão entre significado e validade. A tese semântica fundamental de Dummett é que nós compreendemos uma sentença quando temos conhecimento de como poderíamos defender sua verdade e que consequências, importantes para nossa ação, proveriam dela se nós a aceitássemos como verdadeira. Isto, na realidade já exprime uma declaração crítica que se espera que o ouvinte aceite de um falante quando este executa um ato de fala e levanta pretensão de validade para o conteúdo de seu proferimento. Assim, o ouvinte compreende o proferimento na medida em que tem conhecimento dos motivos que legitimam sua aceitação intersubjetiva e suas consequências. Isto decorre da concepção pragmática de compreensão e entendimento segundo a qual se mede o sucesso ilocucionário de uma ação linguística pelo sim ou não dados a pretensões de validade criticáveis.

2) A comunicação, orientada ao entendimento, que é essencialmente de caráter discursivo, constitui-se de dois níveis fundamentais: o nível da ação e o nível do discurso. No nível da ação comunicativa, efetivada no contexto de um mundo de vida comum, são levantadas ingenuamente pretensões de validade consideradas evidentes em si mesmas. Na medida em que são problematizadas e se tornam objeto de uma controvérsia fundamentada em razões, seus participantes migram de uma ação comunicativa para um outro tipo de comunicação, isto é, para uma práxis argumentativa

\begin{tabular}{|c|c|c|c|c|}
\hline Qevista Dialectus & Ano 10 & n. 24 & Setembro - Dezembro 2021 & p. $131-163$ \\
\hline
\end{tabular}


em que pretendem mutuamente chegar a um consenso e também aprender uns dos outros. $\mathrm{Na}$ base de pressuposições de comunicação deste discurso racional transformadas, as opiniões do mundo da vida, até então tidas como pano de fundo não problematizado, são submetidas à prova em relação à sua validade. Neste contexto se revela a distinção básica entre sentenças descritivas sobre algo no mundo objetivo e sentenças normativas sobre obrigatoriedades no mundo social.

L. B. Puntel considera esse "conceito de razão" o pressuposto metodológico central do pensamento de Habermas, entendido por ele não num quadro ontológico, transcendental ou analítico, mas exclusivamente num contexto comunicativo uma vez que é um elemento constituinte da estrutura da comunicação que se revela no comportamento de sujeitos engajados na fala e na ação. Ao apresentar argumentos e interpretar entendimentos, esses sujeitos confiam em regras intuitivamente assimiladas no mundo de suas práticas quotidianas. A racionalidade é plenamente alcançada quando estas pretensões se tornam objetivo de uma acareação. Desta forma, razão/racionalidade é essencialmente uma forma de justificação pública. A filosofia tem aqui como tarefa o esclarecimento dos procedimentos e normas de que depende nossa deliberação pública, ou seja, os modos de justificação usados em nossas deliberações públicas, nossas e dos outros participantes. Desta forma, a tarefa de filosofia consiste em "analisar e articular a racionalidade inerente à validade básica do falar quotidiano" (PUNTEL L.B., $O$ pensamento pós-metafísico de Habermas: uma crítica, 2013, 184).

3) Para Habermas, o que era epistemologicamente considerado como a constituição de dois campos da realidade, na pragmática formal, esses campos são elevados a sistemas de relacionamento inteiramente formais ou "mundos" que formam os sistemas gramaticais de relacionamento para tudo o que se possa encontrar no mundo tanto no que diz respeito a objetos como a possíveis relações interpessoais e normas, ou seja, tanto no mundo objetivo enquanto totalidade de objetos como no mundo das interações sociais. Isto significa dizer que sem essa postulação de um mundo objetivo as práticas no mundo da vida se tonam impossíveis: enquanto sujeitos capazes de linguagem e ação, os usuários da linguagem devem ser capazes de referir-se a algo no mundo objetivo justamente a partir do horizonte de seu mundo de vida partilhado. Só assim é possível entender-se acerca de algo na comunicação uns com os outros. Essas mesmas pressuposições pragmáticas dos usuários da linguagem fazem os agentes que enfrentam desafios práticos. Ambos pressupõem um mundo objetivo partilhado como a totalidade de objetos com os quais lidam e julgam (HABERMAS J., Wahrheit und Rechtfertigung, 
1999, 24). Por essa razão, a postulação de uma coisa em si perde qualquer sentido. Habermas pensa os objetos numa perspectiva nominalista: o mundo é a totalidade de objetos individuais espaço-temporais a respeito de que podemos atribuir fatos.

Neste contexto, é fundamental, para Habermas, distinguir com clareza entre o mundo de vida, linguisticamente estruturado, que constitui o pano de fundo implícito dos participantes de uma conversa e estabelece o contexto das conversas e a fonte dos conteúdos da comunicação, e a suposição formal de um mundo objetivo e de um mundo social que os participantes de uma comunicação e os agentes fazem em suas referências linguísticas ou em seus relacionamentos práticos com algo no mundo, o que, segundo Habermas, não faz R. Brandom, pois seu realismo conceitual nivela mundo da vida e mundo objetivo (HABERMAS J., Wahrheit und Rechtfertigung, 1999, 15).

No entanto, a mesma objeção feita a Brandom pode, segundo Puntel, ser feita a Habermas, que trabalha com o mesmo quadro teórico de Brandom, uma vez que Habermas chega ao mundo objetivo através da análise dos discursos e das ações de falantes e agentes no processo de comunicação. Isto significa dizer que também em Habermas tudo é pensado a partir das práticas sociais, o que significa dizer que ele não transcende o mundo da comunicação, ou seja, “o 'mundo objetivo' articulado pelo uso de termos singulares consiste apenas de elementos do mundo da vida", o que se contrapõe ao objetivo de Habermas de pensar um mundo de objetos independente. "Em outras palavras, a fim de articular um mundo objetivo genuinamente independente, a dimensão do mundo da vida deve ser superada ou transgredida... Isto não pode ser feito dentro do quadro referencial filosófico da pragmática-comunicativa de Habermas". A razão disso é que aqui as sentenças são articuladas de acordo com um operador teórico pragmaticamente restrito: "Desde a perspectiva de falantes e agentes no espaço comunicativo que acontece no mundo da vida é o caso que eles se referem a objetos..." (PUNTEL L.B., O pensamento pós-metafísico de Habermas: uma crítica, 2013, 204).

4) Ainda está em aberto uma questão fundamental: como os universais pragmáticos, que são constitutivos tanto para a ação orientada ao entendimento como para o discurso racional e o relacionamento ao mundo das sentenças, podem romper com o etnocentrismo das visões linguísticas de mundo e dos mundos de vida linguisticamente estruturados uma vez que a dimensão comunicativa da linguagem não possui de antemão em si este potencial de universalização. Os resultados dos processos de aprendizado que se efetivam no interior dos horizontes particulares de significado só podem modificar os limites de um mundo linguisticamente revelado quando o saber do mundo não só é 
possibilitado pelo saber linguístico, mas por adquirir frente a este uma "força de revisão" que é fruto do processamento discursivo das experiências feitas.

5) Nas decepções experimentadas, revela-se um fracasso performativo em relação ao mundo, dificilmente negável, seja na contradição ao mundo objetivo seja na contradição a uma outra forma de vida em dissonância com a nossa. Neste contexto retorna, de outra maneira, a distinção entre ação e discurso, ou seja, não como diferença linguística interna de duas formas de comunicação, mas como diferença entre linguagem e ação não linguística, pois, em diferença dos procedimentos do discurso já apresentados, em relação à postura hipotética dos participantes, deve-se ainda acrescentar o que Habermas denomina uma "fantasia adutiva" para "aprender do mundo" e corrigir préopiniões empíricas. Aqui tem um significado imediato, para o aprendizado mútuo, a forma de comunicação dos discursos racionais que rompem com as limitações contextuais.

6) O conceito de linguagem, adotado pela pragmática formal, provém do conceito de um empreendimento discursivo entre os participantes de um diálogo em que eles levantam pretensões de validade para seus proferimentos. Essas pretensões se diferenciam segundo duas perspectivas: verdade (pretensão para sentenças sobre coisas e eventos no mundo objetivo) e correção (pretensão para sentenças sobre expectativas normativas e relações interpessoais que pertencem a um mundo social só acessíveis numa postura performativa). Aqui a função cognitiva da linguagem adquire uma independência relativa em relação à função de abertura do mundo justamente em processos de aprendizagem sócio morais como também na dimensão do lidar com a realidade externa. Por essa razão, uma teoria da ação comunicativa, radicada nesta concepção de linguagem, pode encontrar conexões com uma teoria materialista da sociedade e alcançar uma avaliação diferenciada da modernização cultural e social, distanciando-se da crítica pósmoderna da razão.

d) A diferença fisionômica entre a tradição analítica e a tradição hermenêutica

Uma teoria analítica da linguagem, que se restringe à problemática epistemológica herdada da teoria do conhecimento, não possui geralmente sensibilidade e muito menos um acesso adequado a questões do tempo atual, o discurso filosófico da modernidade, algo que foi trabalhado pela chamada filosofia continental. Neste contexto, Habermas articula um novo confronto com Heidegger com a intenção de esclarecer sua própria posição retornando ao horizonte de pensamento aberto por Humboldt.

\begin{tabular}{|c|c|c|c|c|}
\hline Qonista Dialectus & Ano 10 & n. 24 & Setembro - Dezembro 2021 & p. $131-163$ \\
\hline
\end{tabular}


Para Habermas, a crítica da cultura perpassa todo o pensamento de Heidegger. $\mathrm{Na}$ segunda fase de seu pensamento, depois da "virada (Kehre)", há uma lúcida confrontação com o cartesianismo e um confronto com Nietzsche que inspiraram tanto a crítica de base ampla à ciência e à tecnologia como, sobretudo, as características totalitárias de nosso tempo, temas já trabalhados noutra ótica por Weber e Lukács. Na realidade, sua análise da realidade, articulada no seio de sua crítica à metafísica, apresenta-nos uma contrapartida idealista à crítica materialista à coisificação. O que interessa, sobretudo, a Habermas na análise de Heidegger é o caráter do destino diagnosticado da modernidade, pois, apesar de o diagnóstico não ser original, ele estiliza os fenômenos de uma auto conservação selvagem como fatalidade de um poder de destino que entra na história. Com esta análise, Heidegger nos pode ajudar muito com a condição que deixemos de lado a hipostasia da função linguística de abertura do mundo, que é central em sua crítica à metafísica, o que nos torna possível articular uma outra visão da modernidade tematizando uma dialética entre abertura do mundo e processos de aprendizagem intramundanos, o que nos permite retornar a Humboldt.

Em Humboldt não encontramos uma contribuição própria expressiva da crítica à modernidade, mas ele capta as consequências disfuncionais do bloqueio da função social integrativa do entendimento linguístico: a linguagem vincula enquanto singulariza mostrando, assim, que individualização e socialização se entrelaçam. A partir desta perspectiva é possível compreender as patologias sociais características como perturbações da interação social mediada comunicativamente. Para Habermas isto tem consequências epistemológicas: já que aqui o objetivo é a análise e a explicação de padrões de comunicação sistematicamente destorcida, a filosofia perde a competência exclusiva. Humboldt, em contraposição a Heidegger, sugere uma divisão de trabalho entre filosofia e teoria social capaz de levar a sério o mundo vida, reproduzido pela ação comunicativa, como fonte de solidariedade social. Essa proposta é, contudo, consciente de que esta solidariedade está permanentemente em perigo de ser oprimida e destruída pelos outros dois mecanismos de integração social, ou seja, pelos mercados e pelas burocracias. Desta forma, em contraposição a Heidegger, a modernidade não é ameaçada pela doação indeterminada e sinistra do ser, mas por imperativos sistêmicos, sobretudo econômicos, que esvaziam as fontes de solidariedade social provenientes do mundo da vida.

Habermas articula sua proposta de filosofia a partir da reviravolta linguística e as correntes e os problemas que se articularam neste cenário filosófico. Em sua proposta 
de articulação da filosofia se exprime uma tese simplesmente central: a pragmática exerce aqui um papel absolutamente central, o que significa dizer que sua proposta tem na linguagem quotidiana sua base. L. B. Puntel faz um questionamento radical a esta postura. Sua proposta de filosofia pretende pôr-se no nível teórico que atingimos em nossos dias, o que permite à filosofia recuperar sua tarefa originária própria e desenvolver de forma adequada suas potencialidades.

Ele articula uma Metafísica Estrutural (PUNTEL L.B., Estrutura e ser, 2008, 97 e ss.) que parte da concepção fundamental de que filosofia é uma atividade humana que se distingue de outras atividades humanas precisamente porque seu objetivo básico é o desenvolvimento e a exposição de teorias. Ela é assim constitutivamente um empreendimento teórico. Em radical contraposição ao pragmatismo da proposta de Habermas, ele vai insistir no aspecto teórico para mostrar a diferença radical entre racionalidade comunicativa e racionalidade teórica em sentido estrito, ou a tese fundamental aqui é que a linguagem filosófica adequada não é a linguagem da comunicação, mas uma linguagem de exposição porque se trata na filosofia de uma teoria no sentido estrito, o que significa dizer que aqui fatores pragmáticos não têm lugar. Deste modo, a questão central aqui é determinar o que é propriamente uma teoria.

Importante para a compreensão do que está aqui em jogo é para Puntel uma comparação com a postura transcendental, assumida também por Habermas, que é conduzida por uma concepção determinada das sentenças teórico-declarativas. Esta concepção é uma decorrência do princípio básico da concepção transcendental que se exprimiu com toda clareza na famosa declaração de Kant na Crítica da Razão Pura: “O Eu penso tem que poder acompanhar todas as minhas representações" (KrV B 131). Este princípio fundamental é articulado linguisticamente na forma de um operador que explícita ou implicitamente é pré-posto a cada sentença teórica e que se pode exprimir assim: "a partir da perspectiva do sujeito/eu transcendental é o caso que p".

Esta posição, contudo, não é sustentável, porque ela contém uma incoerência interna: na medida em que se tenta articular e legitimar o próprio ponto de vista transcendental, o procedimento aqui não é mais transcendental assim que as sentenças não podem ser expressas com o operador transcendental "a partir da perspectiva do sujeito transcendental", mas simplesmente com o operador "é o caso que", pois do contrário teríamos um círculo vicioso.

Quando Kant, por exemplo, articula a asserção que se tem que distinguir entre fenômeno e coisa-em-si e que a coisa-em-si é e permanece para o espírito finito 
incognoscível, ele capta e articula um estado de coisas que detona o quadro transcendental uma vez que aqui o estado de coisas se refere à relação ou à interconexão entre conhecimento e fenômeno/coisa-em-si. Ora assim já se tematiza algo a respeito da relação/interconexão, o que segundo o quadro teórico transcendental justamente não é possível. Quando uma posição filosófica se articula a partir apenas de um dos lados da interconexão mencionada entre dimensão estrutural e dimensão objetiva ela falha na tarefa: captar a interconexão ou a unidade da relação mesma em que desaparece qualquer referência a sujeito, falante, ação etc.

Neste sentido preciso se pode dizer que a articulação aqui "tem um status absoluto e universal no sentido de que ela articula irrestritamente um conteúdo intelectual: 'é simpliciter o caso que...' Qualquer explicitação que não atinja este nível absoluto e universal não é uma teoria no sentido genuíno" (PUNTEL L.B., O pensamento pósmetafísico de Habermas: uma crítica, 2013, 187). Com isto, toda sentença com um operador teórico estritamente irrestrito situa o que é por ela expresso num espaço teórico estritamente irrestrito. Assim, o operador teórico genuíno é universal no sentido de que exprime a perspectiva absolutamente universal. Portanto, sentenças precedidas por um operador estritamente teórico não contêm referência a sujeitos e suas ações, a suas práticas como é o caso na racionalidade comunicativa ou a qualquer outro fator particular (PUNTEL L.B., Estrutura e ser, 2008, 118 e ss.; Ser e Deus, 2011,152 e s.).

Para Puntel, isso não significa dizer que o proferimento de uma sentença genuinamente teórica não ocorra através de um sujeito. Uma atividade de um sujeito é sempre pressuposta, mas não no sentido de uma ação particular de um sujeito. Está em jogo aqui uma ação absolutamente universal de um sujeito, pois na execução de uma sentença genuinamente teórica o sujeito está presente, porém de tal forma que ele se elevou à dimensão absolutamente universal. Aqui qualquer particularidade é supressa justamente porque o sujeito atingiu aquela dimensão que é coextensiva com a dimensão absolutamente universal. Por esta razão sua nomeação se torna supérflua.

Assim, o que impede considerações apresentadas enquanto teorias de serem teorias em sentido genuíno é o fato de serem apresentadas na dependência de restrições como por exemplo no caso da filosofia transcendental que utiliza o operador transcendental: "Desde a perspectiva da subjetividade transcendental é o caso que o sol esquenta a pedra". As teorias enquanto tais são totalmente independentes de qualquer fato externo que as restringe, o que não impede que eles existam, mas enquanto tais são externos às teorias. Portanto, uma articulação teórica "não nega ou exclui estes 'fatores 
contingentes', mas os transcende de tal modo que não tem qualquer relação explicitamente essencial com eles. O que há articulado dentro daquilo que pode convenientemente ser chamado de dimensão teórica é algo único: o que é articulado é o que é o caso simpliciter" (PUNTEL L.B., O pensamento pós-metafísico de Habermas: uma crítica, 2013, 188).

A partir daqui é possível explicitar com clareza o status da proposta de Habermas: a racionalidade comunicativa "se articula em sentenças governadas por um operador teórico extremamente restrito, ou seja, o operador: 'desde a perspectiva da razão/racionalidade comunicativa é o caso que..." (PUNTEL L.B., O pensamento pósmetafísico de Habermas: uma crítica, 2013, 188). Desta forma, Habermas não atinge um pensamento genuinamente universal, o que significa dizer que uma teoria não se pode reduzir à racionalidade comunicativa. Isto não quer dizer que Habermas não use implicitamente sentenças com um operador irrestritamente universal. $\mathrm{O}$ caso mais claro é o da tentativa de explicitar sua própria posição filosófica, o que revela a impossibilidade de uma teoria filosófica evitar o operador estritamente universal. Essa necessidade tem implicações simplesmente decisivas para a articulação de uma teoria filosófica.

\section{Referências}

AGGAZZI E., A objetividade científica e seus contextos, São Leopoldo: Ed. UNISINOS, 2020.

AIUB M./GONZALEZ M.E.Q./BOENS M.C. (orgs.), Filosofia da Mente, ciência cognitiva e o pós-humano: par onde vamos? São Paulo: FiloCzar, 2015.

APEL K-O, Der Denkweg von Charles S. Peirce. Eine Einführung in den amerikanischen Pragmatismus, Frankfurt am Main: Suhrkamp, 1975; Transformation der Philosophie, Vol. 1, Frankfurt am Main: Suhrkamp, 1976.

BRANDOM R. B., Making it Explicit. Reasoning, Representing and Discursive Commitment, Cambridge/MA, London: University Press, 1994.

BRYANT L./SRNICEK N./HARMAN G. (orgs.), The Speculative Turn. Continental Materialism and Realism, Melbourne: re-press, 2011.

CARMO L.A.D. do. Discurso filosófico e a arquitetônica da ética do discurso. Apel versus Habermas, Fortaleza: Ed. UECE, 2011.

DUMmeTt M., Language and Communication, in: The Seas of Language, Oxford: Oxford University Press, 1993. 
FLICKINGER H-G., Da experiência da arte à hermenêutica filosófica, in: ALMEIDA C.L.S. de/ FLICKINGER H-G./ ROHDEN L. (orgs.), Hermenêutica filosófica. Nas trilhas de Hans-Georg Gadamer, Porto Alegre: Edipucrs, 2000.

GADAMER H-G., Wahrheit und Methode. Grundzüge einer philosophischen Hermeneutik, 3a. ed., Tübingen: J.C.B. Mohr (Paul Siebeck), 1972.

GRONDIN J., Hermeneutische Wahrheit? Zum Wahrheitsbegriff Hans- Georg Gadamers, 2a. ed., Weinheim: Beltz Athenäum Verlag, 1994.

HABERMAS J., Wahrheit und Rechtfertigung, Philosophische Aufsätze, Frankfurt am Main: Suhrkamp, 1999; Nachmetaphysisches Denken. Philosophische Aufsätze Philosophische Aufsätze, Frankfurt am Main: Suhrkamp, 1988; Da semântica formal à pragmática transcendental, in: ethic@, v.19 n. 3 (2020)487-517.

HEIDEGGER M., Unterwegs zur Sprache, Pfulingen: Neske, 1989.

HÖSLE V., Eine kurze Geschichte der deutschen Philosophie. Rückblick auf den deutschen Geist, München: C.H Beck, 2013.

OLIVEIRA M.A.O. de, Moral, Direito e Democracia: o debate Apel versus Habermas no contexto de uma concepção procedimental da filosofia prática, in: MOREIRA L.(org.), Com Habermas contra Habermas: Direito, Discurso e Democracia, São Paulo: Landy Editora, 2004, p. 145-176; É a filosofia uma Pragmática?, in: Tempo Brasileiro n. 181/182, 2010.

PUNTEL L.B., Estrutura e ser. Um quadro referencial teórico para uma filosofia sistemática, São Leopoldo: Ed. UNISINOS,2008; Ser e Deus. Um enfoque sistemático em confronto com M. Heidegger, É Lévinas e J-L. Marion, São Leopoldo: Ed. UNISINOS,2011; O pensamento pós-metafísico de Habermas: uma crítica, in: Síntese, vol. 40, n. 127, 2013, 173-223.

QUINE W. van Orman, The Pragmatistsplace in Empiricism, in: MULVANEY R./ZELTNER PH. (orgs.), Pragmatism: its sources and prospects, University of South California Press, 1981.

RORTY R., Der Spiegel der Natur, Frankfurt am Main: Suhrkamp, 1981.

WITTGENSTEIN L., Philosophische Untersuchungen, Frankfurt am Main: Suhrkamp Verlag, 1967. 